\title{
Estimating Frost during Growing Season and Its Impact on the Velocity of Vegetation Greenup and Withering in Northeast China
}

\author{
Guorong Deng ${ }^{1,2} \mathbb{D}^{\mathbb{D}}$, Hongyan Zhang ${ }^{1,2, *}$, Lingbin Yang ${ }^{1,2}$, Jianjun Zhao ${ }^{1,2} \mathbb{D}^{\mathbb{D}}$, Xiaoyi Guo ${ }^{1,2} \mathbb{D}$, \\ Hong Ying ${ }^{1,2}$, Wu Rihan ${ }^{1,2}$ and Dan Guo ${ }^{3}$ \\ 1 Key Laboratory of Geographical Processes and Ecological Security in Changbai Mountains, Ministry of \\ Education, School of Geographical Sciences, Northeast Normal University, Changchun 130024, China; \\ denggr272@nenu.edu.cn (G.D.); yanglb872@nenu.edu.cn (L.Y.); zhaojj662@nenu.edu.cn (J.Z.); \\ guoxy914@nenu.edu.cn (X.G.); hongy864@nenu.edu.cn (H.Y.); wurh651@nenu.edu.cn (W.R.) \\ 2 Urban Remote Sensing Application Innovation Center, School of Geographical Sciences, Northeast Normal \\ University, Changchun 130024, China \\ 3 College of Resources and Environment, Jilin Agricultural University, Changchun 130024, China; \\ guodan@jlau.edu.cn \\ * Correspondence: zhy@nenu.edu.cn; Tel.: +86-431-8509-9550
}

Received: 31 March 2020; Accepted: 23 April 2020; Published: 25 April 2020

\begin{abstract}
Vegetation phenology and photosynthetic primary production have changed simultaneously over the past three decades, thus impacting the velocity of vegetation greenup (Vgreenup) and withering (Vwithering). Although climate warming reduces the frequency of frost events, vegetation is exposed more frequently to frost due to the extension of the growing season. Currently, little is known about the effect of frost during the growing season on Vgreenup and Vwithering. This study analyzed spatiotemporal variations in Vgreenup and Vwithering in Northeast China between 1982 to 2015 using Global Inventory Modeling and Mapping Studies Normalized Difference Vegetation Index (GIMMS 3g NDVI) data. Frost days and frost intensity were selected as indicators to investigate the influence of frost during the growing season on Vgreenup and Vwithering, respectively. Increased frost days during the growing season slowed Vgreenup and Vwithering. The number of frost days had a greater impact on Vwithering compared to Vgreenup. In addition, Vgreenup and Vwithering of forests were more vulnerable to frost days, while frost days had a lesser effect on grasslands. In contrast to frost days, frost intensity, which generally decreased during the growing season, accelerated Vgreenup and Vwithering for all land cover types. Changes in frost intensity had less of an impact on forests, whereas the leaf structure of grasslands is relatively simple and thus more vulnerable to frost intensity. The effects of frost during the growing season on Vgreenup and Vwithering in Northeast China were highlighted in this study, and the results provide a useful reference for understanding local vegetation responses to global climate change.
\end{abstract}

Keywords: climate change; greenup; withering; frost; Northeast China

\section{Introduction}

Global climate change is rapidly altering surface vegetation and impacting the functioning of ecosystems [1]. Vegetation phenology, is an important indicator of dynamic changes in plant landscapes and can be used to reveal the growth dynamics of vegetation and directly reflect the response and feedback process of ecosystems to global climate change [2,3]. Phenology, in the context of global climate change, has been widely studied at different scales [4-6]. A number of studies have demonstrated the earlier start of season (SOS), start of peak season (SOP), and end of peak season 
(EOP) due to climate change, while end of season (EOS) has been delayed in the northern hemisphere over the past three decades as indicated by both in situ and via remote sensing observations [7-12]. The trends of earlier and later phenology have resulted changes of the duration of vegetation greenup (Dgreenup, defined as the time span from SOS to SOP) and withering (Dwithering, defined as the time span from EOP to EOS), which is referred to as an extended vegetation growing season [13]. Changes in the growing season affect the carbon cycle of terrestrial ecosystems, which also have complex effects on the growth cycle of vegetation.

The earth is experiencing a gradual greening process due to the comprehensive influence of various factors [14-16] such as regional climate change (temperature, precipitation and solar radiation) [17], and the impacts of fertilization and elevated carbon dioxide [18]. This trend in global greening is considered to increase the photosynthetic capacity of vegetation, and changes in NDVI amplitude during vegetation greenup (Agreenup, defined as the NDVI amplitude between SOS and SOP) and withering (Awithering, defined as the NDVI amplitude between EOP and EOS). Vegetation phenology and photosynthetic primary production may change simultaneously because of the complex interaction between vegetation and climate, which can impact the velocity of vegetation greenup (Vgreenup, defined as the ratio of Agreenup to Dgreenup) and withering (Vwithering, defined as the ratio of Awithering to Dwithering) [19-21]. Changes in Vgreenup and Vwithering might affect the carbon, water and energy cycles of ecosystems and the response of vegetation to regional climates [22-24]. Currently, the spatial patterns and related changes in Vgreenup and Vwithering at a regional scale are not clear. Therefore, researching the spatial-temporal variations of Vgreenup and Vwithering would help to improve our understanding of current vegetation dynamics and the responses of vegetation to climate change.

Frost, a meteorological phenomenon caused by low temperatures, has a number of ecological impacts including loss of stored carbon and nutrients, and the alteration of species interactions [25-27]. Records of air temperature and remote sensing observations indicate that the date of the last spring frost is advancing [28,29], the earliest autumn frost date is being delayed [30,31], and the frost-free season is extending in the northern hemisphere [32,33]. Although climate warming reduces the frequency and intensity of frost, recent studies have demonstrated that the vegetation is more frequently exposed to frost in temperature-limited ecosystems due to the extension of the growing season [34]. Global warming is likely to result in different patterns of frost, depending on the specific climatic conditions of the area. Therefore, it is necessary to study the effect of frost change on vegetation on a regional scale rather than a larger spatial scale. Previous studies have highlighted the changes in the timing and frequency of frost, and the effects of frost on vegetation phenology [35-37], however, the response of different Vgreenup and Vwithering to frost has not been fully studied.

Northeast China is located in the mid-latitudes of the Northern Hemisphere and is one of the regions in China that is most sensitive and earliest to respond to climate change [38]. The study area exhibits extensive natural diversity with respect to vegetation, and the perennial cold climate provides good conditions for investigating the impact of frost events on Vgreenup and Vwithering. In the current study, we reconstructed annual Vgreenup and Vwithering in Northeast China using the third generation Global Inventory Modeling and Mapping Studies Normalized Difference Vegetation Index (GIMMS 3g NDVI) data from 1982-2015, and the Princeton Global Forcing dataset to investigate the spatial distribution of frost days and frost intensity during the growing season at the pixel scale in order to address the following questions: (1) Are the trends in frost days and frost intensity during the growing season consistent with those in the Northern Hemisphere? (2) How did Vgreenup and Vwithering change in different ecological regions throughout the study period? (3) How do changes in frost during the growing season affect Vgreenup and Vwithering within the study domain? (4) How do different land cover types respond to frost at different vegetation growth stages? 


\section{Materials and Methods}

\subsection{Study Area}

The study area $\left(115^{\circ} 32^{\prime} \mathrm{E}\right.$ to $135^{\circ} 10^{\prime} \mathrm{E}, 38^{\circ} 42^{\prime} \mathrm{N}$ to $\left.53^{\circ} 35^{\prime} \mathrm{N}\right)$ is located in Northeast China, and covers an area of 1.18 million $\mathrm{km}^{2}$ (Figure 1 ). The region is characterized by a temperate monsoon climate, with high temperatures and precipitation in the summer, and cold temperatures and low precipitation in the winter. The central region of the study area is dominated by plains and is composed of the Songnen and Liaohe Plain. The west, north and eastern parts of the study area are surrounded by the Greater Khingan Mountains, the Lesser Khingan Mountains and the Changbai Mountains, respectively. The natural vegetation in the study area mainly includes deciduous broadleaf forests, deciduous needleleaf forests, mixed forests, savannas, woody savannas, and grasslands. Forests are distributed throughout the mountainous areas. Grasslands, savanna and woody savanna make up the majority of the western part of the study area.

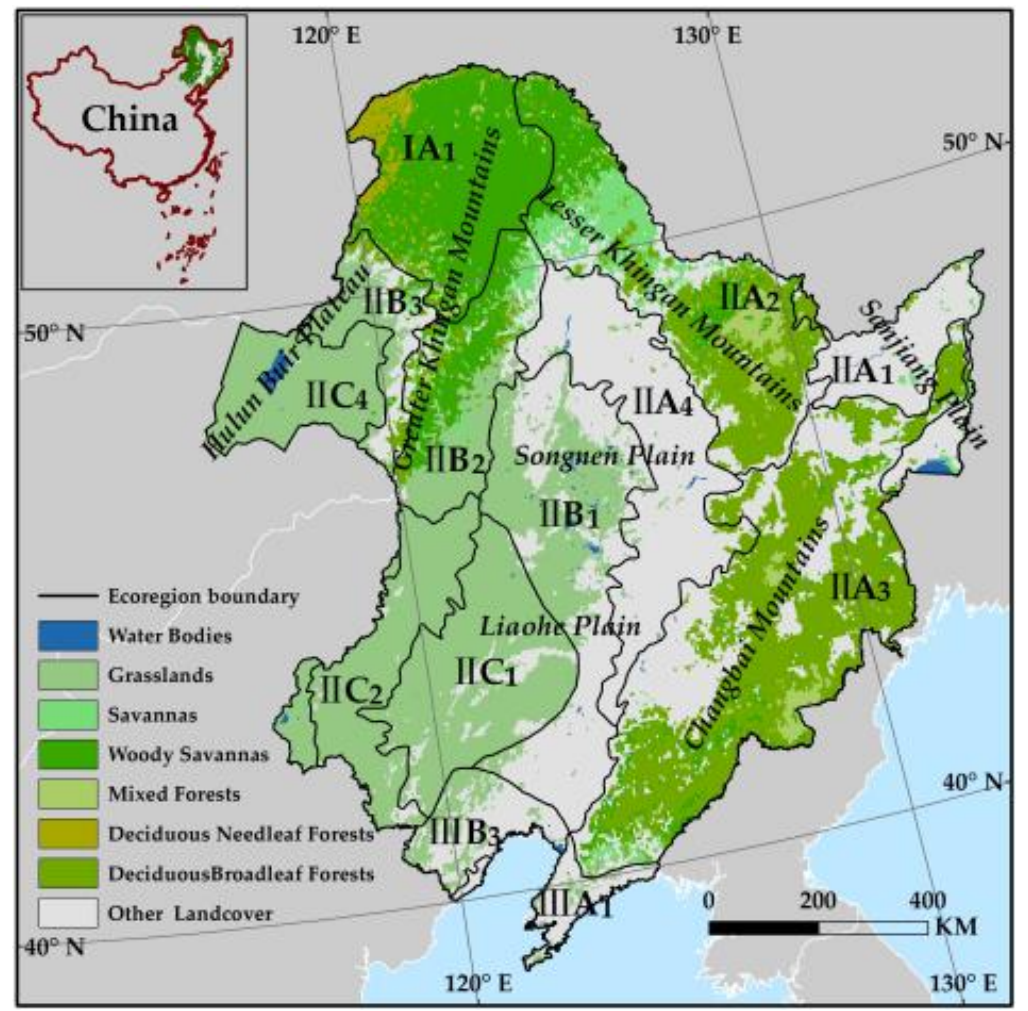

Figure 1. Location of the study area and spatial distribution of main land cover types.

The study area is composed of 13 ecological regions [39]: (IA 1$)$ north Greater Khingan Mountain deciduous coniferous forest region; (IIA 1 ) Sanjiang Plain wetland region; $\left(\mathrm{IIA}_{2}\right)$ Lesser Khingan Mountain broadleaved and coniferous forest region; $\left(\mathrm{IIA}_{3}\right)$ Changbai Mountains broadleaved and coniferous forest region; (IIA 4 ) piedmont platform of eastern Songliao Plain broadleaved and coniferous mixed forest region; $\left(\mathrm{IIB}_{1}\right)$ middle Songliao Plain forest-steppe region; $\left(\mathrm{IIB}_{2}\right)$ middle Greater Khingan Mountains steppe-forest region; ( $\mathrm{IIB}_{3}$ ) hill land of north part of western Greater Khingan Mountains piedmont forest-steppe region; $\left(\mathrm{IIC}_{1}\right)$ western Liaohe River Plain steppe region; $\left(\mathrm{IIC}_{2}\right)$ southern Greater Khingan Mountain steppe region; $\left(\mathrm{IIC}_{4}\right)$ Hulun Buir Plain steppe region; $\left(\mathrm{IIIA}_{1}\right)$ eastern Liaoning and Jiaodong hill land deciduous broadleaved forest and cultivated vegetation region; and (IIIB 3 ) North China Mountains deciduous broadleaved forest region. 


\subsection{Data Processing}

\subsubsection{GIMMS 3g NDVI}

The GIMMS 3g NDVI [40] (https://ecocast.arc.nasa.gov/data/pub/gimms/3g.v1/, version 3g.v1) was used to calculate Vgreenup and Vwithering. The long time-series NDVI dataset used the maximum value composite (MVC) method to minimize the effects of clouds, water vapor, solar angle and aerosols [41]. The dataset covered the period from July 1981 to December 2015 with a 15-day temporal resolution and $1 / 12^{\circ}$ spatial resolution.

\subsubsection{Meteorological Data}

The daily minimum temperature ( $\mathrm{T}_{\mathrm{MIN}}$ ) was collected from the Princeton Global Forcings dataset (version 3, http://hydrology.princeton.edu/data.pgf.php) [42] and used to calculate the number of the frost days and accumulated frost degree days during vegetation greenup and withering. Daily average temperature $\left(\mathrm{T}_{\text {MEAN }}\right)$, precipitation and downward shortwave at surface (dswrf) were used to assess the impact of climatic factors on Vgreenup and Vwithering. The Princeton Global Forcings dataset models hydrological and land-surface processes using global observations at a spatial resolution of 0.25 degrees. All meteorological data used in this study were resampled using the nearest neighbor assignment method at the spatial resolution of the GIMMS dataset.

\subsubsection{Landcover Dataset}

The Moderate Resolution Imaging Spectroradiometer (MODIS) global land cover type products (MCD12C1, collection 6) from 2001 to 2015 and land use and land cover (LULC) maps collected in the 1980s by the National Earth System Science Data Center, National Science \& Technology Infrastructure of China (http://www.geodata.cn) were used to classify the land cover type in the study area. MCD12C1 defines various classification schemes, and the International Geosphere-Biosphere Programme (IGBP) global vegetation classification scheme was used in this study, together with LULC maps. In order to reduce the impact of land cover change on the analysis based on different land cover types, if the same landcover types of MCD12C1 and LULC maps intersected during the study period they were classified as unchanged pixels. The spatial resolution of MCD12C1 and LULC maps was $0.05^{\circ}$ and $5 \mathrm{~km}$, respectively. Unchanged land cover pixels were resampled (nearest neighbor assignment method) to the same spatial resolution as the GIMMS dataset.

\subsection{Methods}

\subsubsection{Calculation of Velocity of Vegetation Greenup and Withering}

The Savitzky-Golay (S-G) filter was used to fit the annual vegetation growth curves in this study. The S-G filter retains details of the NDVI time series and smooths the curve in accordance with the vegetation growth law, which is beneficial for the high precision information extraction of vegetation phenology. The timing of $20 \%$ of the NDVI amplitude was used as the SOS and EOS, and the timing of $80 \%$ of the NDVI amplitude was used as the SOP and EOP (Figure 2). This process was completed in TIMESAT software (version 3.3) [43] and the following parameters were specified: seasonal parameters of 1 , the number of envelope iterations of 2, an adaptation strength of 3, and a SG window size of 3. Based on the methodology of Wang et al. [19], Vgreenup was defined as the ratio of Agreenup to Dgreenup. Similarly, Vwithering was defined as the ratio of Awithering to Dwithering:

$$
\begin{gathered}
\text { Vgreenup }=\frac{\text { Agreenup }}{\text { Dgreenup }}=\frac{\mathrm{NDVI}_{\mathrm{SOP}}-\mathrm{NDVI}_{\mathrm{SOS}}}{\mathrm{SOP}-\mathrm{SOS}} \\
\text { Vwithering }=\frac{\text { Awithering }}{\text { Dwithering }}=\frac{\left|\mathrm{NDVI}_{\mathrm{EOS}}-\mathrm{NDVI}_{\mathrm{EOP}}\right|}{\mathrm{EOS}-\mathrm{EOP}}
\end{gathered}
$$




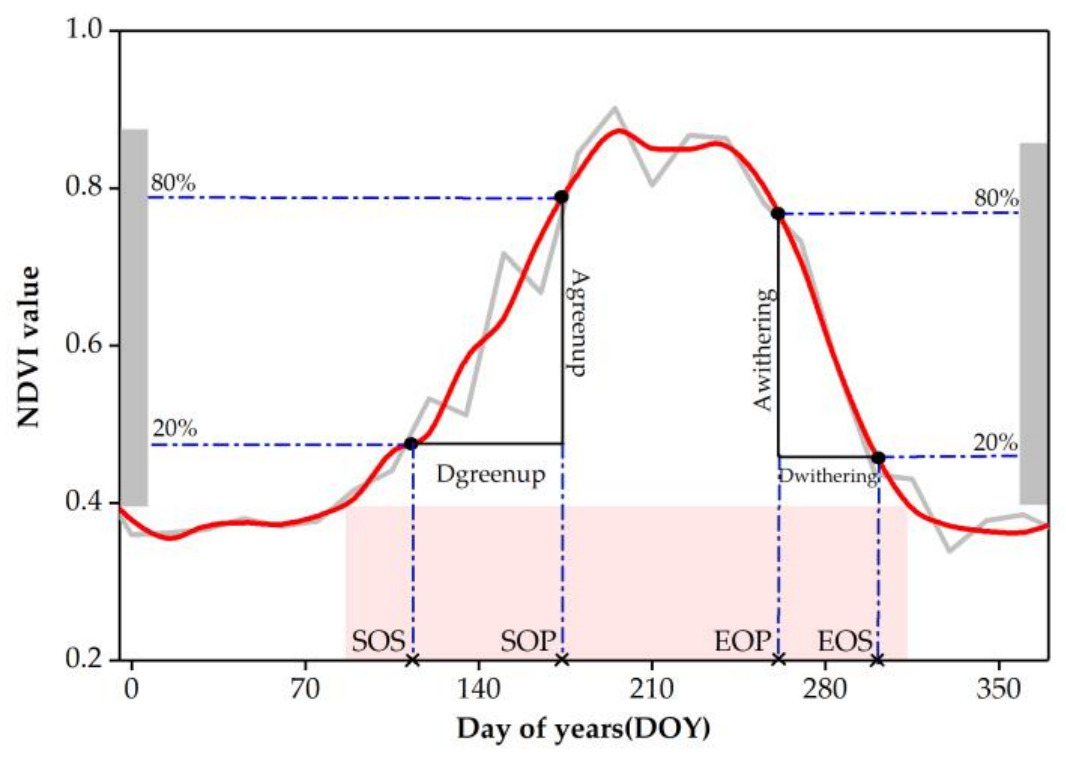

Figure 2. Calculation of vegetation greenup velocity and withering velocity; grey lines represent the annual vegetation growth curve and the red curve is the line of best fit using the S-G filter; the gray strips on the left and right represent the amplitude of NDVI during vegetation greenup and withering, respectively, the prink strips represent base value.

\subsubsection{Defining Frost Indices in Growing Seasons}

Rather than define all the frost days in spring or autumn, we focused only on the number of frost days that occurred in the vegetation growing season. The frost days in the growing season were divided into two parts that corresponded to Dgreenup and Dwithering. The number of frost days during the vegetation greenup (VGFDs) was defined as:

$$
\text { VGFDs }=\sum_{S O S}^{S O P} \text { frost days }
$$

Similarity, the number of frost days during vegetation withering (VWFDs) were defined as:

$$
\mathrm{VWFDs}=\sum_{E O P}^{E O S} \text { frost days }
$$

where frost days were defined as days with $\mathrm{T}_{\mathrm{MIN}}<0{ }^{\circ} \mathrm{C}$.

The average accumulated frost degree days (AFDD) [44] was defined as the mean value of the accumulated temperature lower than the frost threshold during the study period, and was used as an index to measure frost intensity. Average AFDD during vegetation greenup was calculated as follows:

$$
\text { average } \mathrm{AFDD}_{V G}=\frac{\sum_{S O S}^{S O P} \max \left(\mathrm{Th}-\mathrm{T}_{\mathrm{MIN}}, 0\right)}{S O P-S O S}
$$

Similarity, average AFDD during vegetation withering was calculated as:

$$
\text { average } \mathrm{AFDD}_{V W}=\frac{\sum_{E O P}^{E O S} \max \left(\mathrm{Th}-\mathrm{T}_{\mathrm{MIN}}, 0\right)}{E O S-E O P}
$$

where, Th represents the frost threshold temperature. The sensitivity of Vgreenup (Vwithering) to average AFDD in the threshold temperature range of $-2{ }^{\circ} \mathrm{C}$ to $2{ }^{\circ} \mathrm{C}$ was evaluated to determine the frost threshold in this study (Figure S1). Vgreenup and Vwithering was most sensitive to average AFDD at the threshold temperature of $2{ }^{\circ} \mathrm{C}$ and $-2{ }^{\circ} \mathrm{C}$, respectively. 


\subsubsection{Investigation of the Sensitivity of the Vegetation Greenup and Withering to Frost Days}

The sensitivity of Vgreenup (or Vwithering) to frost days, defined as the change in Vgreenup (or Vwithering) per unit change of number of frost days [45], was the regression coefficient of the frost days using multiple linear regression. Vgreenup (or Vwithering) was the dependent variable, while climatic parameters (temperature, precipitation and solar radiation) and frost days in Dgreenup (or Dwithering) were used as independent variables. The general form of a multiple linear regression model is [46]:

$$
\mathrm{Y}=\beta_{0}+\beta_{1} X_{1}+\beta_{2} X_{2}+\cdots+\beta_{k} X_{k}+\mu
$$

where, $\mathrm{k}, \beta_{0}$ and $\mu$ represent the number of independent variables, a constant term and random error, respectively. $\beta_{1}, \beta_{2} \cdots \beta_{k}$ is the regression coefficient. Similarity, the sensitivity of Vgreenup (or Vwithering) to AFDD was calculated by replacing the frost days in the above formula with AFDD.

\subsubsection{Statistical Analyses}

Sen's slope [47] was used to assess temporal trends in Vgreenup, Vwithering, frost days and AFDD at the pixel scale from 1982 to 2015. In contrast to the linear trend fit by least squares, Sen's slope removes the interference of individual abnormal values and reduces the influence of missing data on the results [48]. Mann-Kendall [49,50] is a nonparametric statistical test that does not require samples to obey a particular distribution. In this study, Mann-Kendall was used to investigate the significance of trends for Vgreenup, Vwithering, frost days and AFDD.

Partial correlation analysis was used to evaluate the relationship between Vgreenup (or Vwithering) and frost to eliminate the effects of other climatic factors, whereby Vgreenup (or Vwithering) and frost days (or mean AFDD) were set as dependent variables and independent variables, respectively.

$\mathrm{T}_{\mathrm{MEAN}}$, precipitation, and solar radiation were set as controlling variables. AFDD and $\mathrm{T}_{\mathrm{MEAN}}$ are the average values during Dgreenup (or Dwithering), and VGFDs (or VWFDs), precipitation, and solar radiation were accumulated during Dgreenup (or Dwithering).

\section{Results}

\subsection{Spatial Variability in Frost during the Growing Season}

The spatial distribution of the VGFDs and VWFDs in Northeast China from 1982 to 2015 was calculated using the mean number of pixels whose daily TMIN was less than $0{ }^{\circ} \mathrm{C}$ during Dgreenup and Dwithering (Figure 3a,b). The spatial patterns of VGFDs exhibited good spatial consistency with VWFDs, while the frequency of frost days in Dwithering was significantly higher than that during Dgreenup. The mean VGFDs and VWFDs in Northeast China were $10.12 \pm 7.90$ days/year and $24.45 \pm 12.14$ days/year, respectively. The largest number of frost days was found in the northern Greater Khingan Mountains and the southern Lesser Khingan Mountains region. The number of frost days gradually decreased with decreasing latitude. Frost occurs more frequently in high altitude areas, while the plain area had the lowest frequency of frost days during the growing season (Figure S2).

The spatial distribution of AFDD in Dgreenup and Dwithering was consistent with the frost days in the corresponding period (Figure 3c,d). Frost intensity increased with increasing latitude and altitude. Similar to seasonal differences in frost days, frost intensity during vegetation withering was higher than that in the process of greenup, with average AFDD of $4.65 \pm 1.86^{\circ} \mathrm{C} /$ day and $1.29 \pm$ $0.28^{\circ} \mathrm{C} /$ day, respectively. Results show that the frequency of vegetation exposure to frost was lower and the intensity of frost was smaller during vegetation greenup than during vegetation withering. 

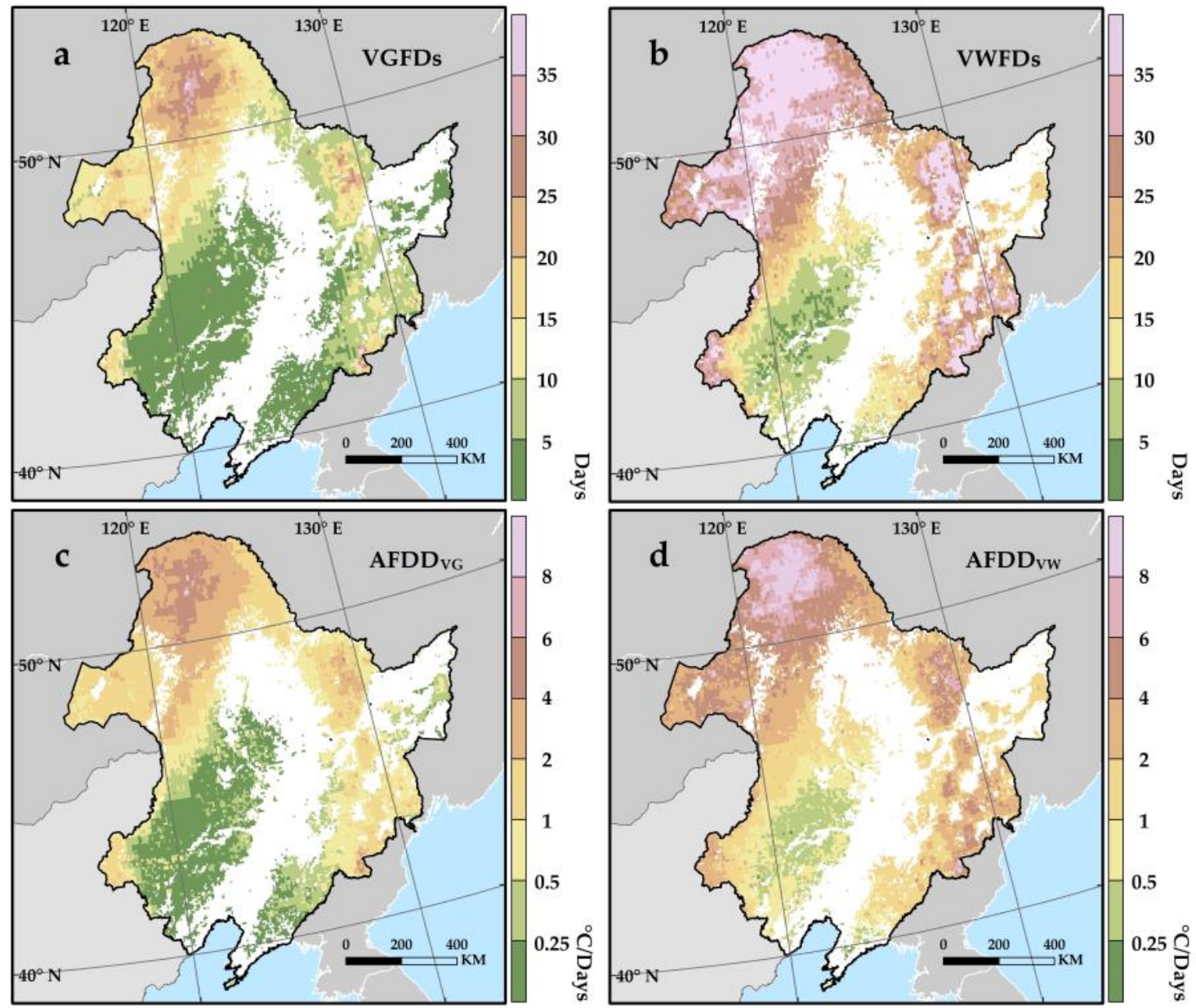

Figure 3. Spatial distribution of average values of (a) frost days during vegetation greenup (VGFDs); (b) frost days during vegetation withering (VWFDs); (c) average accumulated frost degree days during vegetation greenup $\left(\mathrm{AFDD}_{\mathrm{VG}}\right)$; and (d) average accumulated frost degree days during vegetation withering $\left(\mathrm{AFDD}_{\mathrm{VW}}\right)$.

\subsection{Temporal Variability of Frost during the Growing Season}

During the study period, $63.66 \%$ of the VGFDs pixels showed a positive trend, with a mean increasing rate of $0.3 \pm 0.06$ days/decade (Figure $4 \mathrm{a}$ ). In contrast, a negative trend in VGFDs was mainly distributed in the southern Lesser Khingan Mountains, northern Changbai Mountains, and western Hulunbeier Plateau, while only $5.43 \%$ of the study area pixels passed the significance test $(p<0.05$, Figure S3a). More VWFDs pixels (74.44\%) show a positive trend, and the overall positive trend observed for VWFDs was stronger than that of VGFDs with an average increase of $1.50 \pm 0.15$ days/decade (Figure $4 \mathrm{~b}$ ). The pixels that showed a significant increase in VWFDs were distributed in the Greater Khingan Mountains and Lesser Khingan Mountains ( $p<0.05$, Figure S3b). The observed negative trend was concentrated in the Changbai Mountain area, but only $2.23 \%$ of the study area had significant changes $(p<0.05)$.

Average $\mathrm{AFDD}_{\mathrm{VG}}$ in Northeast China had a broad negative trend $(90.01 \%)$, with a decreasing rate of $0.13^{\circ} \mathrm{C} /$ day each decade (Figure $\left.4 \mathrm{c}\right)$. Average $\mathrm{AFDD}_{\mathrm{VG}}$ declined fastest $\left(0.31^{\circ} \mathrm{C} /\right.$ day every decade $)$ in the northern part of the Greater Khingan Mountains, and $10.17 \%$ of the study area pixels passed the significance test ( $p<0.05$, Figure S3c), while the negative trend in western Liaohe River Plain was the weakest. Combined with the generally positive trend in VGFDs, the results show that although the frequency of natural vegetation exposure to frost is increasing in the study area during vegetation 
greenup, the frost intensity is decreasing. The trend in $\mathrm{AFDD}_{\mathrm{VW}}$ had good spatial consistency with the trend in VWFDs, i.e., frost intensity also increased in areas where VWFDs increased, while frost intensity also decreased in the area where the VWFDs decreased. In the study area, AFDD $\mathrm{VW}$ was observed to increase and decrease significantly ( $p<0.05$, Figure S3d), accounting for only $6.18 \%$ and $2.32 \%$ of the study area pixels, respectively.
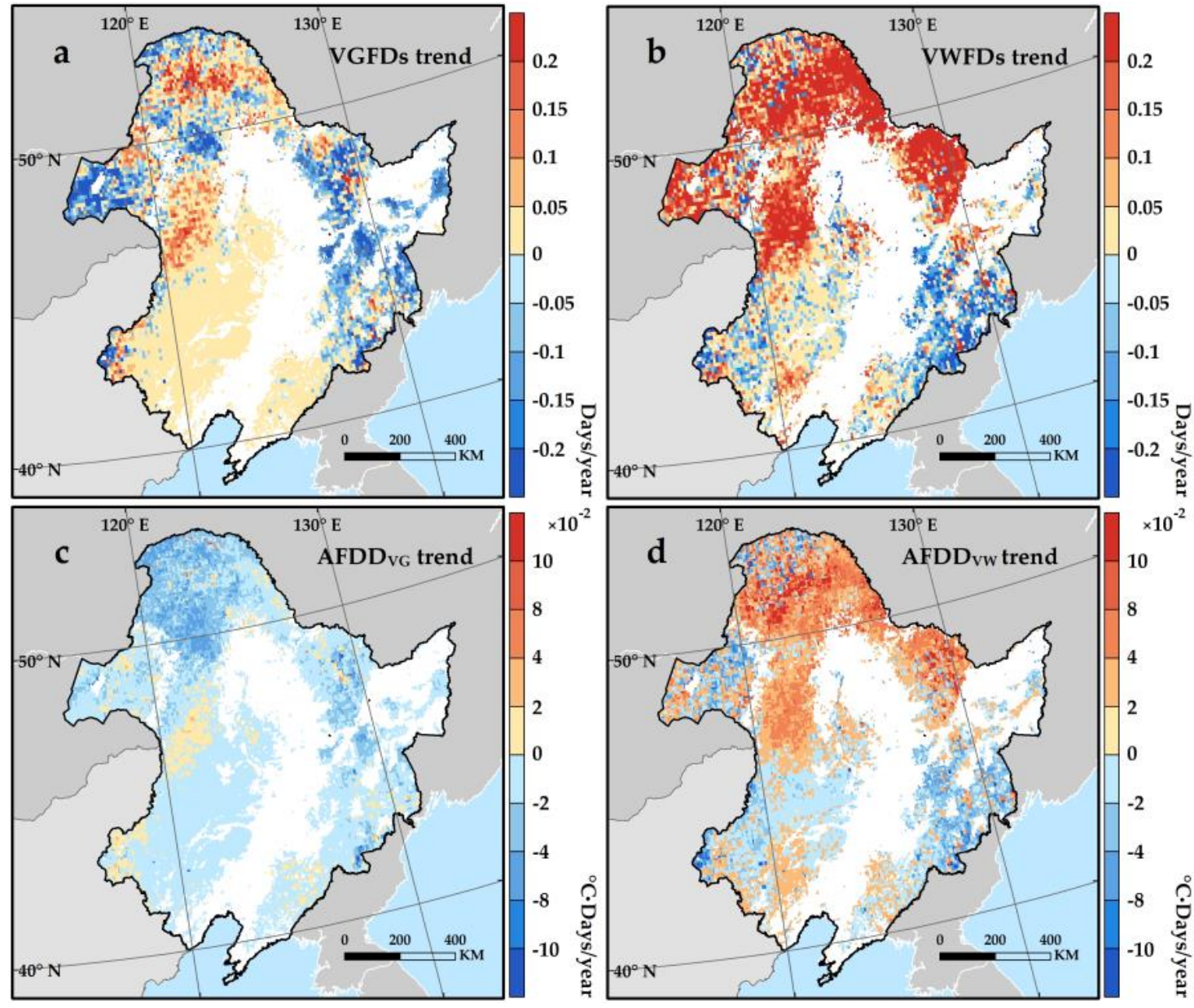

Figure 4. Temporal trends of (a) frost days during vegetation greenup (VGFDs); (b) frost days during vegetation withering (VWFDs); (c) average accumulated frost degree days during vegetation greenup $\left(\mathrm{AFDD}_{\mathrm{VG}}\right) ;(\mathbf{d})$ average accumulated frost degree days during vegetation withering ( $\left.\mathrm{AFDD}_{\mathrm{VW}}\right)$ from 1982 to 2015.

\subsection{Spatial and Temporal Variability of the Velocity of Vegetation Greenup and Withering}

The spatial distribution of Vgreenup in Northeast China from 1982 to 2015 had high spatial heterogeneity, which was ecosystem dependent. Mean Vgreenup was $0.71 \times 10^{-2} /$ day $\left(\mathrm{SD}: 0.28 \times 10^{-2}\right.$ ) for the whole study area (Figure 5a). Areas with high Vgreenup were generally located in mountainous areas and had denser vegetation (average altitude $558.32 \mathrm{~m}$ ) where mixed forest, deciduous broadleaf forest, deciduous needleleaf forest, and woody savannas are the primary land cover types. Areas with lower Vgreenup were concentrated in the central plains and western Hulun Buir Plain (average altitude $226.37 \mathrm{~m}$ ), which are characterized by cover types such as grasslands. Over half $(56.65 \%)$ of the pixels in Vgreenup showed a negative trend in the middle Greater Khingan Mountains steppe-forest region and southern Greater Khingan Mountain steppe region (Figure 5b). At a 95\% confidence level, $10.92 \%$ of study area pixels show a trend to negative Vgreenup (Figure S4a). Vgreenup in the Hulun Buir Plain steppe region and southern portions of the Liaohe Plain had a positive trend. 

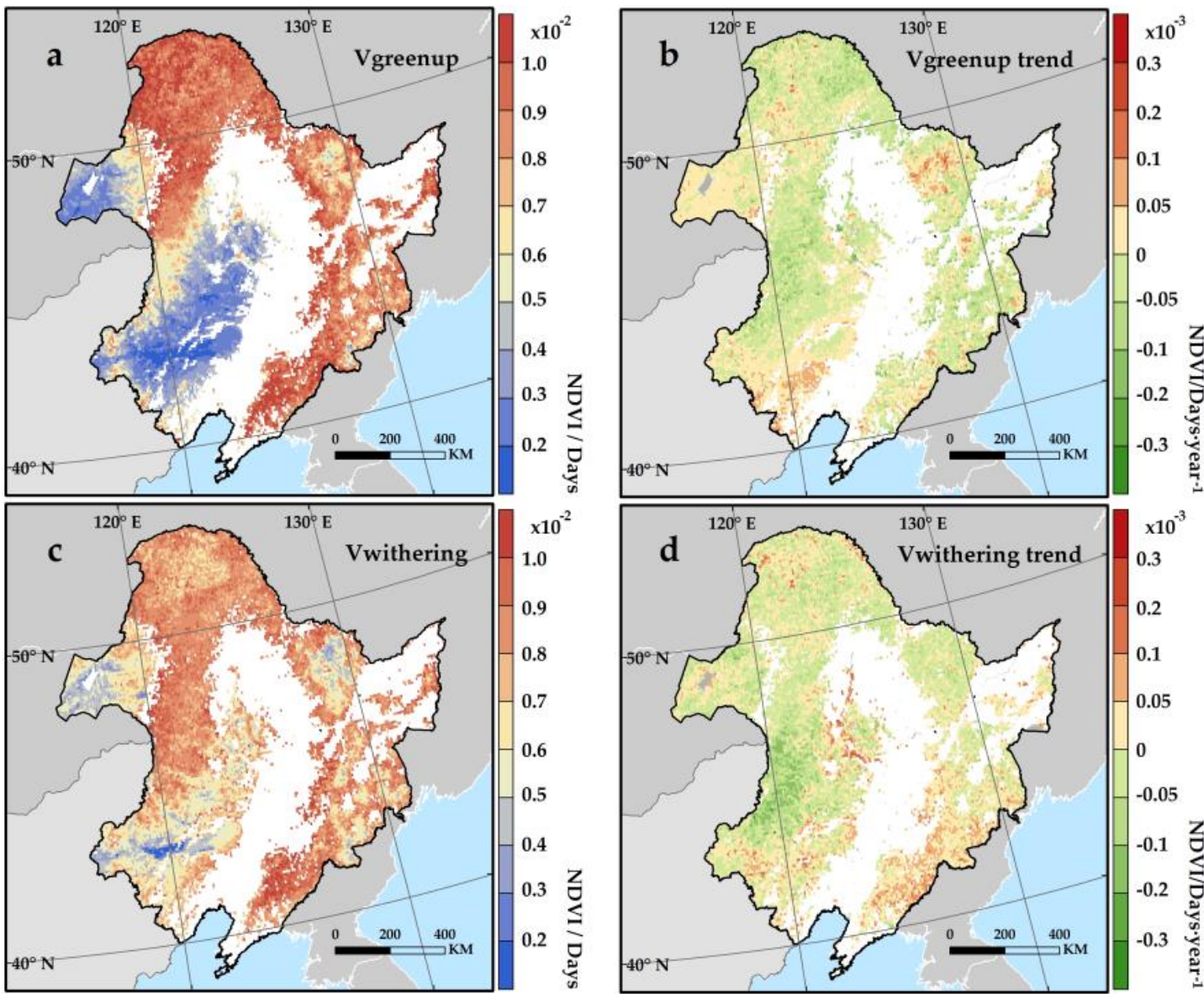

Figure 5. Spatial patterns of velocity of vegetation greenup, withering and their trends in Northeast China from 1982 to 2015: (a) mean velocity of vegetation greenup (Vgreenup); (b) trends in Vgreenup; (c) mean velocity of vegetation withering (Vwithering); (d) trends of the Vwithering.

The spatial patterns for Vwithering in Northeast China were consistent with Vgreenup. It was observed that the Vwithering value was greater than Vgreenup, with an average value of $0.82 \times$ $10^{-2}$ day (SD: $0.16 \times 10^{-2}$, Figure 5 c). High Vwithering occurred in the north and middle part of the Greater Khingan Mountain and the southern Changbai Mountain where the main land cover type was forests, while Vwithering was lowest in grasslands such as the western Liaohe Plain and western Hulun Buir. Over half (52.24\%) of the pixels in Vwithering had a negative trend (Figure $5 \mathrm{~d}$ ) and were mainly distributed in the southern Greater Khingan Mountain steppe region, but only $9.93 \%$ of the pixels had statistical significance $(p<0.05$, Figure S4b). The pixels with a positive trend were mainly distributed in the southern part of the Changbai Mountains and western Liaohe River Plain.

\subsection{Effects of Growing Season Frost on Vgreenup and Vwithering Dynamics}

Frost days occurring during different time periods in the growing season had differing effects on Vgreenup and Vwithering (Figure 6a,b). During vegetation greenup, a negative partial correlation was identified between the Vgreenup and VGFDs in $67.04 \%$ of the study area, which was mainly found in the northern Greater Khingan Mountain, western Hulun Buir Plain. The Changbai Mountains and Liaohe Plain had a weak positive partial correlation. Different from the centralized distribution of positive partial correlation during greenup in the northern part of the study area, a negative partial correlation between VWFDs and Vwithering was found throughout the whole study area $(82.96 \%)$. During the vegetation withering period, $18.12 \%$ of the study area pixels were observed to have a significant negative partial correlation $(p<0.05)$, which was basically consistent with the period of 
vegetation greenup (19.59\%). These results show that the general increase in frost days during the growing season cause a slow-down in Vgreenup and Vwithering.
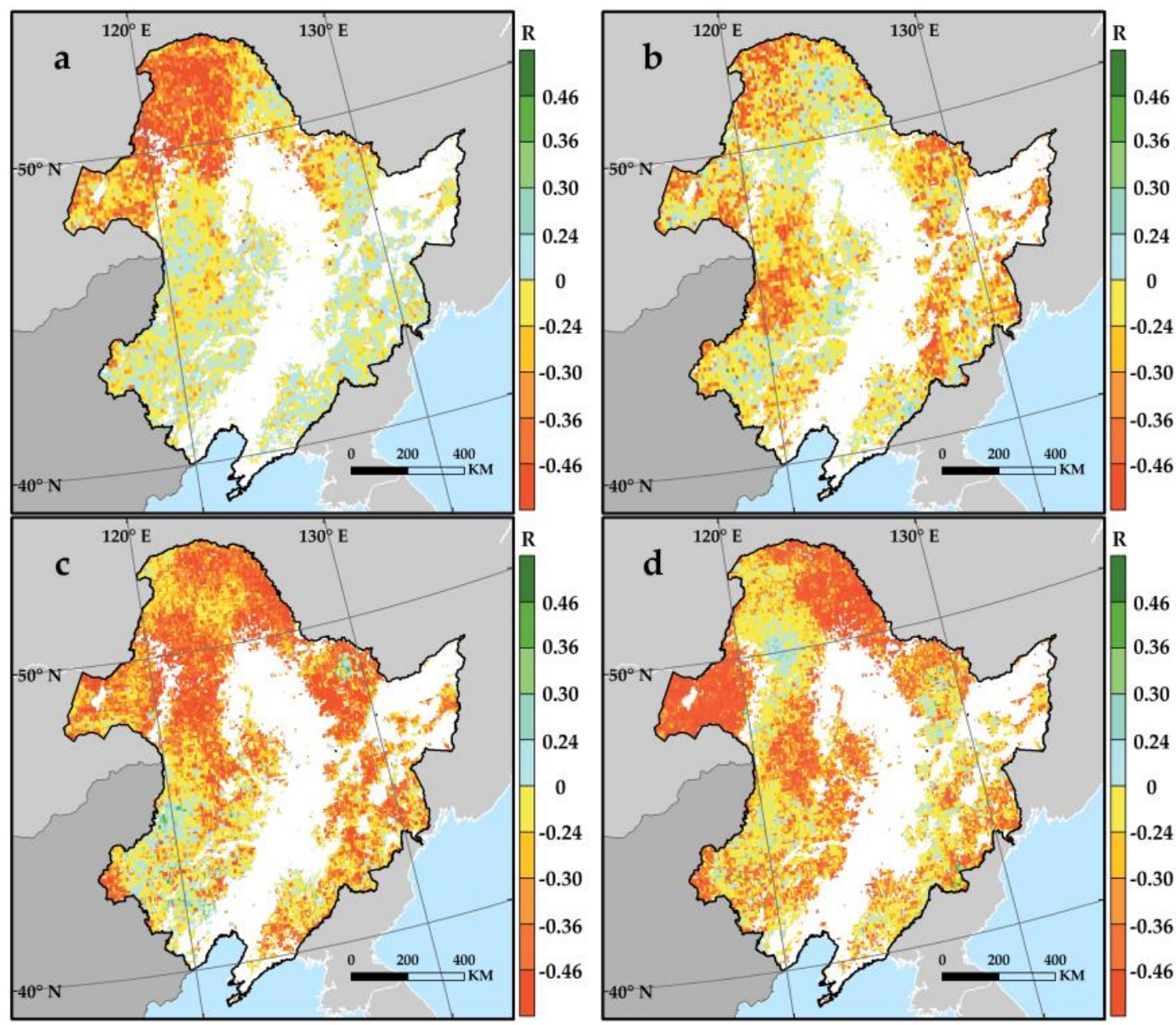

Figure 6. Spatial distribution of partial correlation coefficients between (a) VGFDs and Vgreenup; (b) VWFDs and Vwithering; (c) average AFDD $\mathrm{VG}_{\mathrm{VG}}$ and Vgreenup; (d) average $\mathrm{AFDD}_{\mathrm{VW}}$ and Vwithering. The $1 \%, 5 \%, 10 \%$, and $20 \%$ significance levels of the partial correlations correspond to $\pm 0.46, \pm 0.36$, \pm 0.30 , and \pm 0.24 , respectively.

The negative correlation observed between Vgreenup (Vwithering) and average AFDD, accounted for $90.98 \%$ and $92.14 \%$ of the study area (Figure $6 c, d$ ), respectively. Frost intensity had a greater impact on Vgreenup and Vwithering in the corresponding period than that of frost days, and $41.58 \%$ and $39.26 \%$ of the study area pixels had a significant negative correlation with vegetation greenup and the withering period $(p<0.05)$, respectively. These results demonstrate that a general decrease in frost intensity during the growing season leads to in an increase in Vgreenup and Vwithering.

\subsection{Different Responses to Frost among Land Cover Types}

Across land cover types, there was a negative partial correlation between Vgreenup (Vwithering) and frost in the corresponding period (Table 1). Vgreenup of deciduous needleleaf forest, deciduous broadleaf forest and woody savannas had a significant negative partial relationship with VGFDs, and the correlation $(\mathrm{Rp})$ was $-0.37(p<0.05),-0.38(p<0.05)$ and $-0.36(p<0.05)$, respectively. Except for deciduous needleleaf forest and mixed forest, a significant negative partial correlation between Vgreenup and frost intensity was observed for all other land cover types. The effect of frost days on 
deciduous needleleaf forest was greater than that of frost intensity, while deciduous broadleaf forest, savannas and grasslands were more affected by frost intensity during the greenup period.

Table 1. Partial preseason correlation $\left(\mathrm{R}_{\mathrm{p}}\right)$ between Vgreenup (Vwithering) and frost for different land cover types in Northeast China.

\begin{tabular}{ccccc}
\hline \multirow{2}{*}{ Land Cover Types } & \multicolumn{2}{c}{ Greenup } & \multicolumn{2}{c}{ Withering } \\
\cline { 2 - 5 } & VGFDs & Mean AFDD & VWFDs & Mean AFDD \\
\hline Deciduous needleleaf forest & $-0.37^{*}$ & -0.22 & $-0.50^{* *}$ & -0.32 \\
Deciduous broadleaf forest & $-0.38^{*}$ & $-0.57^{* *}$ & $-0.36^{*}$ & -0.22 \\
Mixed forest & -0.27 & -0.28 & $-0.50^{* *}$ & -0.21 \\
Woody savannas & $-0.36^{*}$ & $-0.47^{* *}$ & -0.20 & -0.32 \\
Savannas & -0.18 & $-0.56^{* *}$ & $-0.40^{*}$ & $-0.38^{*}$ \\
Grasslands & -0.24 & $-0.36^{*}$ & -0.15 & $-0.40^{*}$ \\
\hline
\end{tabular}

Notes: ** indicates the partial correlation between Vgreenup (Vwithering) and frost is significant at $p<0.01$ level, and ${ }^{*}$ indicates a significant partial correlation at $p<0.05$ level.

During the vegetation withering period, except for grasslands and woody savannas, a significant negative partial correlation between Vwithering and VWFDs was observed $(p<0.05)$, in which deciduous needleleaf forest and mixed forest passed the $99 \%$ significance test. In contrast, the negative correlation between Vwithering and frost intensity had a weak influence on different land cover types, and was significant for savannas and grasslands, with a $\operatorname{Rp}$ of $-0.38(p<0.05)$, and -0.40 $(p<0.05)$, respectively.

\section{Discussion}

\subsection{Frost Risk during the Growing Season}

The risk of frost events affecting vegetation in temperate regions has received greater attention in light of climatic changes over recent years [51,52]. Increases in global temperatures have reduced the frequency and intensity of frost [53]. Additionally, Zhou et al. [54] demonstrated that accelerated urbanization in northern China significantly decreases the frequency of cold events. The extension of the vegetation growing season is another impact of the rise in temperatures, which makes vegetation more easily exposed to frost. Although our research demonstrated that frost intensity has generally decreased during vegetation greenup, and will likely continue to decrease in the future [55], this does not mean that the risk of frost to vegetation will decrease. Only $32.13 \%$ of the study area experienced a simultaneous decrease in frost days and frost intensity during vegetation greenup. The early frost-sensitive period increases the risks of the spring frost to vegetation [56]. Vegetation in temperate zones is most vulnerable to freezing when leaves emerge from buds in spring [57], and the vulnerability of leaves during this period will increase greatly with the increase of temperature.

Vegetation exposed to spring frost (without a killing frost) will compensate for damage caused in spring by slowing the velocity of withering [58]. Slower Vwithering means the increased risk of frost in the fall. It is also important to note that our results indicated that the intensity of frost did not decrease as expected in $57.37 \%$ of the study area pixels during the vegetation withering period. Nearly half of the pixels (49.16\%) in the study area showed a positive trend in the number of frost days and frost intensity, and were mainly concentrated in the Greater Khingan Mountains, and the Lesser Khingan Mountains forest areas. Our results suggest that the risk of frost to natural vegetation in Northeast China during greenup and withering periods did not decrease with increases in regional temperatures, however, with the extension of the growing season, the frost risk may increase further.

\subsection{Trends in Vgreenup and Vwithering}

Global warming promotes the growth of vegetation, but phenology is not only related to temperature $[59,60]$. The variables Vgreenup and Vwithering were calculated using Agreenup 
(Awithering) and Dgreenup (Dwithering), and the changes in both directly affect the trend of Vgreenup (Vwithering). All land cover types had positive trends with Agreenup and Awithering (Figure S5), indicating that the photosynthetic capacity of vegetation increased gradually throughout the study period, which is consistent with the results of previous studies [19]. Current air temperatures are far lower than the average temperature at which plants achieve maximum rates of photosynthesis, and ecosystem productivity is still limited by summer temperatures [61]. The photosynthetic capacity of vegetation increases with summer temperatures.

The positive trend observed in Vgreenup was due to an increase in Agreenup and a decrease in Dgreenup. The change observed in Dgreenup was affected by changes in SOS and SOP. Although the dates of SOS and SOP for pixels with a positive trend with Vgreenup were advancing, the rate of increase in SOP was faster than that of SOS (Figure S6). The dates of SOS and SOP for pixels with a negative trend with Vgreenup were also advancing, but the rate of SOP advancement was slower than that of SOS. Therefore, variation in the trend of Vgreenup was restricted by the asymmetric rate of advance of SOS and SOP. Similarly, the generally observed negative trend in Vwithering in the study area was attributed to an advance in EOP dates and the delay of EOS dates leading to an extension of Dwithering. In areas where Vwithering increased, the dates of both EOP and EOS were observed to be delayed, but the delay of EOP dates was greater. Gonsamo et al. [62] demonstrated that peak season for plant activities in temperate terrestrial ecosystems in the northern hemisphere is shifting towards spring, with advances in the dates of SOP and EOP, which is consistent with our results.

\subsection{Impacts of Frost on Vgreenup and Vwithering}

Increases in frost days during vegetation greenup slowed Vgreenup. Although the general decrease in frost intensity promoted the growth of vegetation, a negative trend was still observed in Vgreenup as a whole in the study area. Vegetation requires a particular temperature accumulation during greenup [63]. Decreases in frost frequency and intensity in the preseason (usually defined as the period from the beginning of spring until the SOS date) results in faster accumulation of the required temperature for onset of vegetation greenup. Therefore, advanced SOS dates results in an extension of Dgreenup and decreases in Vgreenup. In addition, newly developed leaves lack the structural integrity to prevent damage during the early stage of vegetation greenup [64,65]. Advances of SOS dates results in an extension of the actual time when vegetation is subjected to frost stress, and these early frost sensitive stages actually increase the frost risks of the vegetation. The growth of newly developed leaves is affected by increased frost risk, which also might decrease Vgreenup. Previous work has demonstrated that vegetation needs to endure certain cold conditions during dormancy [66]. The chilling required for dormancy occurs at temperatures between $0^{\circ} \mathrm{C}$ and $5^{\circ} \mathrm{C}$, and is necessary to shorten the time for vegetation greenup [67]. Although there is insufficient evidence for this demand for cold conditions [68], increases in VGFDs may make it harder to reach temperatures within a specific range, thus increasing the Dgreenup and leading to declines in Vgreenup.

Both frost days and frost intensity were observed to increase in the forest areas of Greater Khingan Mountain and Lesser Khingan Mountain during vegetation withering, which slowed down Vwithering in the area. Most frost events occur at night, while vegetation is only breathing. Although the intensity of late autumn frost does not seriously affect plant tissues, frost events slow down the rates of plant respiration, thereby reducing the vegetation consumption, which leads to the decline in Vwithering. Simultaneously, some studies have observed that withered yellow and deciduous leaves of plants in autumn are strongly related to soil moisture, that is, the increase in soil moisture may slow down the withering of vegetation in this area [69]. Frost events play a role in maintaining soil moisture, and might slow down Vwithering. In addition, if early spring frost damages newly developed leaves, the overall growth of vegetation can be affected. Vegetation will slow down Vwithering in order to balance frost damage received in spring.

The sensitivity of different vegetation Vgreenup and Vwithering to frost in the growing season differs. Species with more phenological sensitivity to climate warming are more vulnerable to frost 
as highlighted by Bennie et al [70]. In addition, the influence of frost on vegetation differs with altitude. Vitasse et al. [71] observed that the risk of frost to vulnerable vegetation tissues (new leaves, flowers and young fruits) increased significantly at higher altitudes, while risk did not change at lower altitudes. Our research demonstrated that frost days and frost intensity had little effect on the Vgreenup and Vwithering of mixed forests, and suggest that the adaptability of mixed forests to frost is stronger than other vegetation types in the study area. Small differences in frost adaptability of different species may affect interspecific competition, thus impacting the functioning and structure of terrestrial ecosystems [26,72]. These results might explain the continuous growth of mixed forest area in Northeast China. The sensitivity of Vgreenup to frost days and frost intensity increased during the vegetation greenup (Figure 7, the verification of multiple linear regression results is shown in Figure S7), and we expect that frost will have a greater impact on Vgreenup in the future. The decreasing sensitivity of Vwithering to frost intensity may indicate that the adaptability of vegetation to frost intensity is increasing, especially in the Greater Khingan Mountain and Lesser Khingan Mountain where frost intensity increased. However, the sensitivity of Vwithering to VWFDs is increasing, and the effect of frost on Vwithering needs to be further studied in the future.
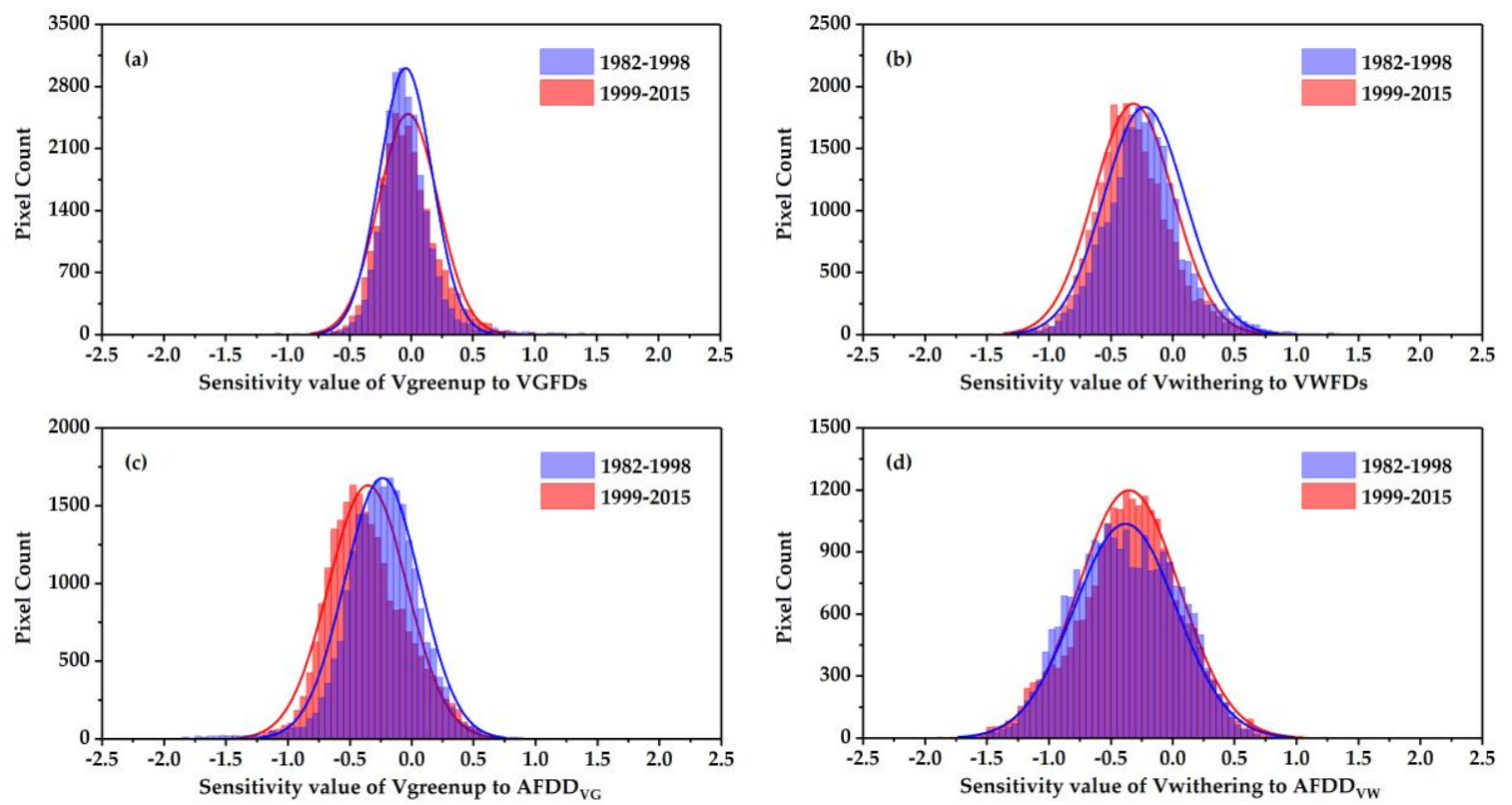

Figure 7. Sensitivity of Vgreenup and Vwithering to frost during the growing season: (a) VGFDs and Vgreenup; (b) VWFDs and Vwithering; (c) AFDD $\mathrm{VG}_{\mathrm{V}}$ and Vgreenup; (d) AFDD $\mathrm{VW}_{\mathrm{W}}$ and Vwithering.

\subsection{Study Limitations}

In this study, the effect of snow cover in spring on the NDVI curve was not effectively removed. Although the maximum value composite method was used with the GIMMS 3g NDVI data to reduce the impact of snow cover to a certain extent, this method still has limitations, which may affect the extraction of the SOS date in the current study. In addition, all meteorological data and land cover data were resampled with the same spatial resolution as GIMMS $3 g$ NDVI $\left(1 / 12^{\circ}\right)$ using the nearest neighbor assignment method. The idea of this resampling method is to segment the pixels with low resolution, and keep the original pixel value, however there is still an associated error that could have influenced the results.

The growing season was divided into a greenup period and withering period to investigate the influence of frost on Vgreenup and Vwithering, respectively. Our research focuses on frost in the growing season, but the frost before SOS also has an influence on SOS dates [73]. The effect of frost before SOS on Vgreenup and Vwithering requires further investigation. In addition, the extraction of 
the remote sensing phenological parameters lacks support from ground verification due to the size of the study area and the length of the study period.

\section{Conclusions}

In this study, Vgreenup and Vwithering in Northeast China were estimated from 1982 to 2015 to assess changes based on GIMMS $3 g$ NDVI data. We investigated changes in frost days and frost intensity during the growing season, and revealed the influence of frost on Vgreenup (Vwithering). Frost days and frost intensity gradually increased with increasing latitude. The number of frost days in both periods showed an increasing trend, and vegetation was more frequently exposed to frost. A negative trend in frost intensity was observed during vegetation greenup, whereas it increased in forested areas in the north of the study area during vegetation withering. Overall, areas with high Vgreenup were generally located at higher altitudes and had denser vegetation, while greatest Vwithering occurred in the central plain. It was observed that Vgreenup and Vwithering had a negative trend in general. Importantly, we found evidence that increased frost days during the growing season slowed Vgreenup and Vwithering, and frost intensity, which generally decreased during the growing season, accelerated Vgreenup and Vwithering. With regard to frost intensity, the Vgreenup and Vwithering of forests was more vulnerable to the number of frost days, while the leaf structure of grasslands is relatively simple and more vulnerable to frost intensity. Our results provide a useful reference for understanding interannual variations in velocity of vegetation greenup and withering in temperate regions and local vegetation responses to global climate change. Considering the potential impact of more frequent frost on vegetation productivity during the growing season, we suggest the development of more integrated strategies to help ecosystems cope with future climate change.

Supplementary Materials: The following are available online at http://www.mdpi.com/2072-4292/12/9/1355/s1, Figure S1: Sensitivity of Vgreenup and Vwithering to frost intensity under different temperature thresholds, Figure S2: The relationship between altitude and VGFDs (VWFDs), Figure S3: Spatial distribution of the significant trend of frost days and frost intensity in the northeast China from 1982 to 2015 during different period, Figure S4: Spatial distribution of the significant trend of Vgreenup and Vwithering in Northeast China during 1982-2015, Figure S5: Spatial distribution of the trend of Agreenup, Awithering, Dgreenup and Dwithering in Northeast China during 1982-2015, Figure S6: Temporal trends of the start and end dates of the greenup period (or withering period) under different Vgreenup and Vwithering trend during 1982-2015, Figure S7: Verification of multiple linear regression results.

Author Contributions: All authors have read and agreed to the published version of the manuscript. All authors contributed equally to this study. Conceptualization, H.Z. and L.Y.; Data curation, G.D., H.Y. and W.R.; Formal analysis, G.D. and W.R.; Methodology, G.D. and D.G.; Writing—original draft, G.D.; Writing—review \& editing, H.Z., J.Z. and X.G.

Funding: This research was funded by the National Natural Science Foundation of China (Grant No. 41871330, 41771450, 41601438 and 41801328), the Fundamental Research Funds for the Central Universities (Grant No. 2412019BJ001 and 2412019FZ002), the Foundation of the Education Department of Jilin Province in the 13th Five-Year project (Grant No. JJKH20190282KJ) and the Science and Technology Development Project of Jilin Province (Grant No. 20180623058TC and 20190802024ZG).

Conflicts of Interest: The authors declare no conflict of interest.

\section{References}

1. Zhu, Z.; Piao, S.; Myneni, R.B. Greening of the Earth and its drivers. Nat. Clim. Chang. 2016. [CrossRef]

2. Hebblewhite, M.; Merrill, E.; Mcdermid, G. A Multi-Scale Test of The Forage Maturation Hypothesis in A Partially Migratory Ungulate Population. Ecol. Monogr. 2008, 78, 141-166. [CrossRef]

3. Jönsson, A.M.; Eklundh, L.; Hellström, M.; Bärring, L.; Jönsson, P. Annual changes in MODIS vegetation indices of Swedish coniferous forests in relation to snow dynamics and tree phenology. Remote Sens. Environ. 2010, 114, 2719-2730. [CrossRef]

4. Sakamoto, T.; Yokozawa, M.; Toritani, H.; Shibayama, M.; Ishitsuka, N.; Ohno, H. A crop phenology detection method using time-series MODIS data. Remote Sens. Environ. 2005, 96, 366-374. [CrossRef]

5. Stoeckli, R.; Vidale, P.L. European plant phenology and climate as seen in a 20-year AVHRR land-surface parameter dataset. Int. J. Remote Sens. 2004, 25, 3303-3330. [CrossRef] 
6. De Beurs, K.M.; Henebry, G.M. Land surface phenology and temperature variation in the International Geosphere-Biosphere Program high-latitude transects. Glob. Chang. Biol. 2005, 11, 779-790. [CrossRef]

7. Tucker, C.J.; Slayback, D.A.; Pinzon, J.E.; Los, S.O.; Myneni, R.B.; Taylor, M.G. Higher northern latitude normalized difference vegetation index and growing season trends from 1982 to 1999. Int. J. Biometeorol. 2001, 45, 184-190. [CrossRef]

8. Garonna, I.; de Jong, R.; de Wit, A.J.W.; Mücher, C.A.; Schmid, B.; Schaepman, M.E. Strong contribution of autumn phenology to changes in satellite-derived growing season length estimates across Europe (1982-2011). Glob. Chang. Biol. 2014, 20, 3457-3470. [CrossRef]

9. Garonna, I.; de Jong, R.; Schaepman, M.E. Variability and evolution of global land surface phenology over the past three decades (1982-2012). Glob. Chang. Biol. 2016, 22, 1456-1468. [CrossRef]

10. Piao, S.; Fang, J.; Zhou, L.; Ciais, P.; Zhu, B. Variations in satellite-derived phenology in China's temperate vegetation. Glob. Chang. Biol. 2006, 12, 672-685. [CrossRef]

11. Yang, B.; He, M.; Shishov, V.; Tychkov, I.; Vaganov, E.A.; Rossi, S.; Ljungqvist, F.; Grießinger, J. New perspective on spring vegetation phenology and global climate change based on Tibetan Plateau tree-ring data. Proc. Natl. Acad. Sci. USA 2017, 114. [CrossRef] [PubMed]

12. Myneni, R.B.; Keeling, C.D.; Tucker, C.J.; Asrar, G.; Nemani, R.R. Increased plant growth in the northern high latitudes from 1981 to 1991. Nature 1997, 386, 698-702. [CrossRef]

13. Jeong, S.-J.; Ho, C.-H.; Gim, H.-J.; Brown, M.E. Phenology shifts at start vs. end of growing season in temperate vegetation over the Northern Hemisphere for the period 1982-2008. Glob. Chang. Biol. 2011, 17, 2385-2399. [CrossRef]

14. Piao, S.; Yin, G.; Tan, J.; Cheng, L.; Huang, M.; Li, Y.; Liu, R.; Mao, J.; Myneni, R.B.; Peng, S.; et al. Detection and attribution of vegetation greening trend in China over the last 30 years. Glob. Chang. Biol. 2015, 21, 1601-1609. [CrossRef] [PubMed]

15. Pan, Y.; Birdsey, R.; Fang, J.; Houghton, R.; Kauppi, P.; Kurz, W.; Phillips, O.; Shvidenko, A.; Lewis, S.; Canadell, J.; et al. A Large and Persistent Carbon Sink in the World's Forests. Science (New York, N.Y.) 2011, 333, 988-993. [CrossRef] [PubMed]

16. Mao, J.; Shi, X.; Thornton, P.E.; Hoffman, F.M.; Zhu, Z.; Myneni, R.B. Global Latitudinal-Asymmetric Vegetation Growth Trends and Their Driving Mechanisms: 1982-2009. Remote Sens. 2013, 5, 1484-1497. [CrossRef]

17. Xu, L.; Myneni, R.B.; Chapin, F.S., III; Callaghan, T.V.; Pinzon, J.E.; Tucker, C.J.; Zhu, Z.; Bi, J.; Ciais, P.; Tømmervik, H.; et al. Temperature and vegetation seasonality diminishment over northern lands. Nat. Clim. Chang. 2013, 3, 581-586. [CrossRef]

18. Los, S.O. Analysis of trends in fused AVHRR and MODIS NDVI data for 1982-2006: Indication for a CO2 fertilization effect in global vegetation. Glob. Biogeochem. Cycles 2013, 27, 318-330. [CrossRef]

19. Wang, L.; Tian, F.; Wang, Y.; Wu, Z.; Schurgers, G.; Fensholt, R. Acceleration of global vegetation greenup from combined effects of climate change and human land management. Glob. Chang. Biol. 2018, 24, 5484-5499. [CrossRef]

20. Kern, A.; Marjanović, H.; Barcza, Z. Spring vegetation green-up dynamics in Central Europe based on 20-year long MODIS NDVI data. Agric. For. Meteorol. 2020, 287, 107969. [CrossRef]

21. Park, H.; Jeong, S.-J.; Ho, C.-H.; Kim, J.; Brown, M.E.; Schaepman, M.E. Nonlinear response of vegetation green-up to local temperature variations in temperate and boreal forests in the Northern Hemisphere. Remote Sens. Environ. 2015, 165, 100-108. [CrossRef]

22. Tylianakis, J.M.; Didham, R.K.; Bascompte, J.; Wardle, D.A. Global change and species interactions in terrestrial ecosystems. Ecol. Lett. 2008, 11, 1351-1363. [CrossRef]

23. Caradonna, P.; Iler, A.; Inouye, D. Shifts in flowering phenology reshape a subalpine plant community. Proc. Natl. Acad. Sci. USA 2014, 111. [CrossRef]

24. Richardson, A.D.; Keenan, T.F.; Migliavacca, M.; Ryu, Y.; Sonnentag, O.; Toomey, M. Climate change, phenology, and phenological control of vegetation feedbacks to the climate system. Agric. For. Meteorol. 2013, 169, 156-173. [CrossRef]

25. Ma, Q.; Huang, J.-G.; Hänninen, H.; Berninger, F. Divergent trends in the risk of spring frost damage to trees in Europe with recent warming. Glob. Chang. Biol. 2019, 25, 351-360. [CrossRef]

26. Gu, L.; Hanson, P.; Post, W.; Kaiser, D.; Yang, B.; Nemani, R.; Pallardy, S.; Meyers, T. The 2007 Eastern US Spring Freeze: Increased Cold Damage in a Warming World? BioScience 2008, 58, 253-262. [CrossRef] 
27. Martin, M.; Gavazov, K.; Körner, C.; Hättenschwiler, S.; Rixen, C. Reduced early growing season freezing resistance in alpine treeline plants under elevated atmospheric CO2. Glob. Chang. Biol. 2010, 16, 1057-1070. [CrossRef]

28. Easterling, D. Recent Changes in Frost Days and the Frost-Free Season in the United States. Bull. Am. Meteorol. Soc. 2002, 83, 1327-1332. [CrossRef]

29. Schwartz, M.; Chen, X. Examining the onset of spring in China. Clim. Res. 2002, 21, 157-164. [CrossRef]

30. Kunkel, K.E.; Easterling, D.R.; Hubbard, K.; Redmond, K. Temporal variations in frost-free season in the United States: 1895-2000. Geophys. Res. Lett. 2004, 31. [CrossRef]

31. Menzel, A.; Jakobi, G.; Ahas, R.; Scheifinger, H.; Estrella, N. Variations of the climatological growing season (1951-2000) in Germany compared with other countries. Int. J. Climatol. 2003, 23, 793-812. [CrossRef]

32. Ning, X.; Liu, G.; Zhang, L.; Xiaoyang, Q.; Zhou, S.; Qin, Y. The spatio-temporal variations of frost-free period in China from 1951 to 2012. J. Geogr. Sci. 2017, 27, 23-42. [CrossRef]

33. Manley, G. Variations in the length of the frost-free season. Quart. J. R. Meteorol. Soc. 1946, 72, $180-184$. [CrossRef]

34. Liu, Q.; Piao, S.; Janssens, I.A.; Fu, Y.; Peng, S.; Lian, X.; Ciais, P.; Myneni, R.B.; Peñuelas, J.; Wang, T. Extension of the growing season increases vegetation exposure to frost. Nat. Commun. 2018, 9, 426. [CrossRef]

35. Inouye, D.W. Effects of climate change on phenology, frost damage, and floral abundance of montane wildflowers. Ecology 2008, 89, 353-362. [CrossRef]

36. Augspurger, C. Spring 2007 warmth and frost: Phenology, damage and refoliation in a temperate deciduous forest. Funct. Ecol. 2009, 23, 1031-1039. [CrossRef]

37. Augspurger, C. Reconstructing patterns of temperature, phenology, and frost damage over 124 years: Spring damage risk is increasing. Ecology 2013, 94, 41-50. [CrossRef]

38. Zhao, J.; Wang, Y.; Zhang, Z.; Zhang, H.; Guo, X.; Yu, S.; Du, W.; Huang, F. The Variations of Land Surface Phenology in Northeast China and Its Responses to Climate Change from 1982 to 2013. Remote Sens. 2016, 8, 400. [CrossRef]

39. Wu, S.; Yin, Y.; Zheng, D.; Yang, Q.; Deng, H. Advances in terrestrial system research in China. J. Geogr. Sci. 2016, 26, 791-802. [CrossRef]

40. Pinzon, J.E.; Tucker, C.J. A Non-Stationary 1981-2012 AVHRR NDVI3g Time Series. Remote Sens. 2014, 6, 6929-6960. [CrossRef]

41. Holben, B. Characteristics of Maximum-Value Composite Images from Temporal AVHRR Data. Int. J. Remote Sens. 1986, 7. [CrossRef]

42. Sheffield, J.; Goteti, G.; Wood, E.F. Development of a 50-Year High-Resolution Global Dataset of Meteorological Forcings for Land Surface Modeling. J. Clim. 2006, 19, 3088. [CrossRef]

43. Eklundh, L.; Jönsson, P. TIMESAT for Processing Time-Series Data from Satellite Sensors for Land Surface Monitoring. In Multitemporal Remote Sensing: Methods and Applications; Ban, Y., Ed.; Springer International Publishing: Cham, Switzerland, 2016; pp. 177-194. ISBN 978-3-319-47037-5.

44. Xiao, L.; Liu, L.; Asseng, S.; Xia, Y.; Tang, L.; Liu, B.; Cao, W.; Zhu, Y. Estimating spring frost and its impact on yield across winter wheat in China. Agric. For. Meteorol. 2018, 260, 154-164. [CrossRef]

45. Davy, R.; Esau, I.; Chernokulsky, A.; Outten, S.; Zilitinkevich, S. Diurnal asymmetry to the observed global warming. Int. J. Climatol. 2016. [CrossRef]

46. Thomas, R.; Zhu, P.; Decady, Y. Point estimates and confidence intervals for variable importance in multiple linear regression. J. Educ. Behav. Stat. 2007, 32. [CrossRef]

47. Sen, P.K. Estimates of the Regression Coefficient Based on Kendall's Tau. J. Am. Stat. Assoc. 1968, 63, 1379-1389. [CrossRef]

48. Beck, P.S.A.; Atzberger, C.; Høgda, K.A.; Johansen, B.; Skidmore, A.K. Improved monitoring of vegetation dynamics at very high latitudes: A new method using MODIS NDVI. Remote Sens. Environ. 2006, 100, 321-334. [CrossRef]

49. Mann, H. Non-Parametric Test Against Trend. Econometrica 1945, 13, 245-259. [CrossRef]

50. Kendall, M.; Gibbons, J. Rank Correlation Method. Biometrika 1990, 11-12. [CrossRef]

51. Steven, C.; Khandoker Shuvo, B.; Philip, K.; Jin, H.; Neville, N.; Mark, H. Bayesian space-time model to analyse frost risk for agriculture in Southeast Australia. Int. J. Climatol. 2015. [CrossRef]

52. Korstian, C. Effect of a late spring frost upon forest vegetation in the Wasatch Mountains of Utah. Aspen Bibliogr. 2020, 2, 47-52. [CrossRef] 
53. Kiktev, D.; Sexton, D.; Alexander, L.; Folland, C. Comparison of Modeled and Observed Trends in Indices of Daily Climate Extremes. J. Clim. 2003, 3560-3571. [CrossRef]

54. Yaqing, Z.; Ren, G. Change in extreme temperature event frequency over mainland China, 1961-2008. Clim. Res. 2011, 50, 125-139. [CrossRef]

55. IPCC; Stocker, T.; Qin, D.; Plattner, G.-K.; Tignor, M.; Allen, S.K.; Boschung, J.; Nauels, A.; Xia, Y.; Bex, V.; et al. Climate Change 2013: The Physical Science Basis; Contribution of Working Group I to the Fifth Assessment Report of the Intergovernmental Panel on Climate Change; Cambridge University Press: Cambridge, UK, 2013.

56. Eccel, E.; Rea, R.; Caffarra, A.; Crisci, A. Risk of spring frost to apple production under future climate scenarios: the role of phenological acclimation. Int. J. Biometeorol. 2009, 53, 273-286. [CrossRef]

57. Vitasse, Y.; Lenz, A.; Körner, C. The interaction between freezing tolerance and phenology in temperate deciduous trees. Front. Plant Sci. 2014, 5. [CrossRef]

58. Zohner, C.M.; Rockinger, A.; Renner, S.S. Increased autumn productivity permits temperate trees to compensate for spring frost damage. New Phytol. 2019, 221, 789-795. [CrossRef]

59. He, L.; Asseng, S.; Zhao, G.; Wu, D.; Yang, X.; Zhuang, W.; Jin, N.; Yu, Q. Impacts of recent climate warming, cultivar changes, and crop management on winter wheat phenology across the Loess Plateau of China. Agric. For. Meteorol. 2015, 200, 135-143. [CrossRef]

60. Li, K.; Yang, X.; Tian, H.; Pan, S.; Liu, Z.; Lu, S. Effects of changing climate and cultivar on the phenology and yield of winter wheat in the North China Plain. Int. J. Biometeorol. 2016, 60, 21-32. [CrossRef]

61. Larcher, W.; Biederman-Thorson, M.A. Physiological Plant Ecology; Springer: Berlin, Germany, 1995.

62. Gonsamo, A.; Chen, J.M.; Ooi, Y.W. Peak season plant activity shift towards spring is reflected by increasing carbon uptake by extratropical ecosystems. Glob. Chang. Biol. 2018, 24, 2117-2128. [CrossRef]

63. Deng, G.; Zhang, H.; Guo, X.; Shan, Y.; Ying, H.; Rihan, W.; Li, H.; Han, Y. Asymmetric Effects of Daytime and Nighttime Warming on Boreal Forest Spring Phenology. Remote Sens. 2019, 11, 1651. [CrossRef]

64. Hufkens, K.; Friedl, M.A.; Keenan, T.F.; Sonnentag, O.; Bailey, A.; O’Keefe, J.; Richardson, A.D. Ecological impacts of a widespread frost event following early spring leaf-out. Glob. Chang. Biol. 2012, 18, 2365-2377. [CrossRef]

65. Inouye, D. The ecological and evolutionary significance of frost in the context of climate change. Ecol. Lett. 2000, 3. [CrossRef]

66. Hänninen, H.; Kramer, K. A framework for modelling the annual cycle of trees in boreal and temperate regions. Silva Fennica 2007, 41. [CrossRef]

67. Harrington, C.A.; Gould, P.J.; Clair, J.B.S. Modeling the effects of winter environment on dormancy release of Douglas-fir. For. Ecol. Manag. 2010, 259, 798-808. [CrossRef]

68. Piao, S.; Tan, J.; Chen, A.; Fu, Y.H.; Ciais, P.; Liu, Q.; Janssens, I.A.; Vicca, S.; Zeng, Z.; Jeong, S.-J.; et al. Leaf onset in the northern hemisphere triggered by daytime temperature. Nat. Commun. 2015, 6, 6911. [CrossRef]

69. González, A.; Martin, I.; Ayerbe, L. Response of barley genotypes to terminal soil moisture stress: Phenology, growth, and yield. Aust. J. Agric. Res. 2007, 58. [CrossRef]

70. Bennie, J.; Kubin, E.; Wiltshire, A.; Huntley, B.; Baxter, R. Predicting spatial and temporal patterns of bud-burst and spring frost risk in north-west Europe: The implications of local adaptation to climate. Glob. Chang. Biol. 2010, 16, 1503-1514. [CrossRef]

71. Vitasse, Y.; Schneider, L.; Rixen, C.; Christen, D.; Rebetez, M. Increase in the risk of exposure of forest and fruit trees to spring frosts at higher elevations in Switzerland over the last four decades. Agric. For. Meteorol. 2018, 248, 60-69. [CrossRef]

72. Heikki, H. Boreal and Temperate Trees in a Changing Climate; Springer: Dordrecht, The Netherlands, 2016.

73. Kramer, K.; Friend, A.; Leinonen, I. Modelling comparison to evaluate the importance of phenology and spring frost damage for the effects of climate change on growth of mixed temperate zone deciduous forest. Clim. Res. 1996, 7, 31-41. [CrossRef]

(C) 2020 by the authors. Licensee MDPI, Basel, Switzerland. This article is an open access article distributed under the terms and conditions of the Creative Commons Attribution (CC BY) license (http://creativecommons.org/licenses/by/4.0/). 